\title{
PENENTUAN ALTERNATIF LOKASI IBUKOTA KABUPATEN MOJOKERTO BERDASARKAN STAKEHOLDER
}

\author{
Iman Tunas Pratama, Soesilo Zauhar, Mochamad Rozikin \\ Program Studi Magister Ilmu Administrasi Publik \\ Kekhususan Perencanaan Pembangunan Daerah Universitas Brawijaya \\ Jalan Mayjen Haryono 163 Malang 65145 -Telp (0341) 553737 \\ dhiemaz_plano@yahoo.com
}

\begin{abstract}
ABSTRAK
Penataan daerah melalui tata pemerintahan yang baik merupakan misi setiap daerah. Berdasarkan Undang-Undang Nomor 23 Tahun 2014 dan Permendagri Nomor 30 Tahun 2012 dihasilkan keputusan bahwa perlu adanya pemindahan Ibukota Kabupaten Mojokerto yang saat ini berada di Kota Mojokerto dan dituangkan dalam Rencana Tata Ruang Wilayah (RTRW) Kabupaten Mojokerto. Penelitian ini memiliki tujuan untuk mengidentifikasi prioritas kriteria dalam penentuan lokasi ibukota dan menetapkan lokasi yang terpilih berdasarkan kriteria ibukota Kabupaten Mojokerto. Analisis yang digunakan yaitu Analytical Hierarchy Process (AHP) menggunakan analisis Expert Choice dengan memilih 8 ahli untuk melakukan penilaian terhadap kriteria dan alternatif lokasi ibukota Kabupaten Mojokerto. Berdasarkan hasil analisis diperoleh hasil bahwa urutan prioritas kriteria adalah ketersediaan lahan (1), aksesibilitas (2), ketersediaan sarana prasarana (3), kondisi fisik (4), politik dan keamanan (5), kebijakan (6), kependudukan (7), letak geografis (8) dan historis ((). Sedangkan alternatif Lokasi terpilih Ibukota Kabupaten Mojokerto yang dipertimbangkan dari urutan 9 kriteria berdasarkan ahli maka urutan lokasi yang terpilih adalah Kecamatan Mojosari (1), Kecamatan Sooko (2), Kecamatan Trowulan (3), Kecamatan Jetis (4) dan Kecamatan Bangsal (5)
\end{abstract}

Kata Kunci : pemilihan-alternatif-lokasi, stakeholder, ibukota-kabupaten

\section{ABSTRACT}

Structuring the region through good governance is the mission of every region. Based on Law Number 23 Year 2014 and Permendagri Number 30 Year 2012, he decision is made that there is a need to move the Capital of Mojokerto Regency which is currently located in Mojokerto City and set forth in the Regional Spatial Plan (RTRW) of Mojokerto Regency. This research aims to identify priority criteria in determining the location of the capital and determine the location selected based on the criteria of the capital of Mojokerto regency. The analysis used is Analytical Hierarchy Process (AHP) using Expert Choice by selecting 8 experts to conduct assessment on criteria and alternative location of capital of Mojokerto regency. The analysis result is the priority of criteria are land availability (1), accessibility (2), availability of infrastructure (3), physical condition (4), politics and security (5), policy (6), population (7), geographical (8) and historical (9). While the alternative Capital location of Mojokerto Regency that considered from the order of 9 criterion in sequence is Mojosari district (1), Sooko district (2), Trowulan District (3), Jetis district (4) and Bangsal district (5)

Keywords: alternative location, stakeholder, capital regency

\section{PENDAHULUAN}

Mulai diterbitkannya dan diberlakukannya Undang-Undang nomor 23 Tahun 2014 tentang Pemerintahan Daerah, menjadikan Pemerintah Daerah Kabupaten/Kota memiliki kewenangan dalam mengatur dan mengurus sendiri urusan pemerintahan berdasarkan asas otonomi yang seluas-luasnya. Tata pemerintahan yang baik merupakan misi setiap daerah, yang sangat didambakan oleh para stakeholder pada suatu daerah.

Terkait penataan daerah, untuk menertibkan administrasi tata kepemerintahan, berdasarkan Undang-Undang Nomor 23 Tahun 2014 dan Permendagri Nomor 30 Tahun 2012, serta surat dari Menteri Dalam Negeri RI tanggal
1 Mei 2013, dihasilkan beberapa keputusan diantaranya adalah perlunya pemindahan Ibukota Kabupaten Mojokerto yang saat ini berada di Kota Mojokerto, dan dituangkan ke dalam Rencana Tata Ruang Wilayah (RTRW) Kabupaten Mojokerto. Pemindahan lokasi Ibu Kota Mojokerto harus mempertimbangkan berbagai macam aspek, baik aspek fisik, sosial maupun dari aspek kebijakan. Sehingga pemilihan lokasi ibu Kota Kabupaten Mojokerto nantinya sesuai dengan arahan pengembangan Kabupaten Mojokerto di masa yang akan datang.

Ibukota merupakan pusat pemerintahan yang memiliki status utama dalam suatu roda pemerintahan yang diatur oleh peraturan perundangan yang berlaku. Dalam perannya sebagai pusat pemerintahan, ibukota secara umum 
memiliki beberapa fungsi diantara sebagai fungsi politik dan ekonomi, oleh karena itu ibukota memiliki peranan penting dalam sendi kehidupan bermasyarakat, berbangsa dan bernegara. Ibukota secara umum memiliki karakteristik sebagai wilayah yang memiliki misi pusat pemerintahan, pusat ekonomi dan sebagai wilayah dalam melakukan berbagai diplomasi dengan wilayah lain.

Pada saat lampau, berbagai teori dan penelitian tentang ibukota menempatkan ibukota dengan titik berat lokasi geografis yang berada di tengah (sentral) dalam penetuan lokasi yang paling tepat untuk perkembangan ekonomi wilayah. Teori teresebut telah tertinggal karena berbagai kekurangan yang terlalu berfokus pada faktor geografi, tanpa mempertimbangkan fakor politik, ekonomi, sosial, budaya dan sejarah (Wolfel, 2002).

Pemerintah Daerah Kabupaten Mojoketo, merupakan salah satu Pemerintah Daerah di Provinsi Jawa Timur yang sampai saat ini masih berpusat pada wilayah Kota Mojokerto. Dengan diterimanya surat dari Menteri Dalam Negeri RI tanggal 1 Mei 2013, maka Pemerintah Kabupaten Mojokerto diharapkan segera memiliki ibukota yang berada di wilayah Kabupaten Mojokerto.

Kabupaten Mojokerto terdiri dari 18 Kecamatan dan 304 desa/kelurahan, dimana setiap wilayah memiliki potensi dan karakteristik yang berbeda dengan potensi ungggulan berupa pertanian, industri, pariwisata dan perdagangan jasa. Kabupaten Mojokerto merupakan bagian dari pusat kegiatan nasional "Gerbangkertosusila" dengan Surabaya sebagai inti. Adapun potensi Kabupaten Mojokerto di bidang industri, lebih menitikberatkan pada industri hasil pengolahan pertanian, meski pada perkembangannya kegiatan industri cenderung berkembang kearah kegiatan industri pengolahan hasil tambang dan manufaktur, yang terdiri dari industri kecil, besar dan menengah.

Pada Peraturan Daerah Kabupaten Mojokerto Nomor 9 Tahun 2012 tentang Rencana Tata Ruang Wilayah Kabupaten Mojokerto 20122032, telah diajukan Kecamatan Mojosari sebagai pusat pemerintahan, akan tetapi hingga saat ini hal tersebut belum terlaksana, oleh karena itu peneliti tertarik untuk mengidentifikasi prioritas kriteria dalam penentuan lokasi ibukota di Kabupaten Mojokerto dan menetapkan lokasi yang terpilih berdasarkan kriteria ibukota Kabupaten Mojokerto.

\section{METODE PENELITIAN \\ Variabel Penelitian}

Variabel dalam penelitian ini terdiri atas 8 (delapan) variabel, yaitu letak geografis, kondisi fisik, ketersediaan lahan, historis, kebijakan, politik dan keamanan, aksesibilitas, ketersediaan sarana dan prasarana dan kependudukan. Variabel penelitian dapat dilihat pada Tabel 1 .

Tabel 1. Variabel Penelitian

\begin{tabular}{|c|c|c|}
\hline $\begin{array}{c}\text { Tujuan } \\
\text { Penelitian }\end{array}$ & Variabel & Indikator \\
\hline \multirow{25}{*}{$\begin{array}{l}\text { 1. Mengidentifik } \\
\text { asi prioritas } \\
\text { kriteria dalam } \\
\text { penentuan } \\
\text { lokasi ibukota } \\
\text { di Kabupaten } \\
\text { Mojokerto }\end{array}$} & \multirow[t]{2}{*}{$\begin{array}{l}\text { Letak } \\
\text { geografis }\end{array}$} & $\begin{array}{l}\text { Jarak terhadap } \\
\text { pusat } \\
\text { pemerintahan } \\
\text { lama }\end{array}$ \\
\hline & & $\begin{array}{l}\text { Jarak terhadap } \\
\text { kota sekitar }\end{array}$ \\
\hline & \multirow[t]{3}{*}{$\begin{array}{l}\text { Kondisi } \\
\text { Fisik }\end{array}$} & $\begin{array}{l}\text { Kemiringan } \\
\text { lereng }\end{array}$ \\
\hline & & $\begin{array}{l}\text { Ketersediaan air } \\
\text { bersih }\end{array}$ \\
\hline & & $\begin{array}{l}\text { Kerentanan } \\
\text { bencana }\end{array}$ \\
\hline & \multirow{4}{*}{$\begin{array}{l}\text { Ketersedia } \\
\text { an Lahan }\end{array}$} & Status lahan \\
\hline & & Luas lahan \\
\hline & & Harga Lahan \\
\hline & & Penggunaan lahan \\
\hline & Historis & $\begin{array}{l}\text { Sejarah } \\
\text { pembentukan kota } \\
\text { Sejarah } \\
\text { karisidenan/kasult } \\
\text { anan/kerajaan }\end{array}$ \\
\hline & \multirow[t]{2}{*}{ Kebijakan } & $\begin{array}{l}\text { Rencana Tata } \\
\text { Ruang }\end{array}$ \\
\hline & & $\begin{array}{l}\text { Prosedur } \\
\text { perizinan }\end{array}$ \\
\hline & \multirow[t]{2}{*}{$\begin{array}{l}\text { Politik dan } \\
\text { keamanan }\end{array}$} & $\begin{array}{l}\text { Kesepakatan } \\
\text { masyarakat }\end{array}$ \\
\hline & & $\begin{array}{l}\text { Visi Misi Kepala } \\
\text { Daerah }\end{array}$ \\
\hline & \multirow[t]{2}{*}{$\begin{array}{l}\text { Aksesibilit } \\
\text { as }\end{array}$} & $\begin{array}{l}\text { Sarana dan } \\
\text { prasarana } \\
\text { transportasi }\end{array}$ \\
\hline & & Jaringan jalan \\
\hline & \multirow{4}{*}{$\begin{array}{l}\text { Ketersedia } \\
\text { an Sarana } \\
\text { Prasarana }\end{array}$} & $\begin{array}{l}\text { Fasilitas } \\
\text { kesehatan }\end{array}$ \\
\hline & & Fasilitas ekonomi \\
\hline & & Fasilitas sosial \\
\hline & & Jaringan utilitas \\
\hline & \multirow{5}{*}{$\begin{array}{l}\text { Kependud } \\
\text { ukan }\end{array}$} & Jumlah penduduk \\
\hline & & $\begin{array}{l}\text { Tingkat } \\
\text { pertumbuhan } \\
\text { penduduk }\end{array}$ \\
\hline & & Angkatan kerja \\
\hline & & $\begin{array}{l}\text { Mata pencaharian } \\
\text { penduduk }\end{array}$ \\
\hline & & $\begin{array}{l}\text { Heterogenitas } \\
\text { suku, agama, dan } \\
\text { etnis }\end{array}$ \\
\hline
\end{tabular}




\begin{tabular}{|l|l|l|}
\hline \multicolumn{1}{|c|}{$\begin{array}{c}\text { Tujuan } \\
\text { Penelitian }\end{array}$} & Variabel & \multicolumn{1}{|c|}{ Indikator } \\
\hline 2. $\begin{array}{l}\text { Menetapkan } \\
\text { lokasi yang } \\
\text { terpilih }\end{array}$ & $\begin{array}{l}\text { Prioritas } \\
\text { Kriteria }\end{array}$ & Kecamatan \\
berdasarkan & Tekasi & \\
kriteria & Ibukota & \\
ibukota & & \\
Kabupaten & & \\
Mojokerto & & \\
\hline
\end{tabular}

\section{METODE ANALISIS}

Analisis yang digunakan pada penelitian ini adalah Analytical Hierarchy Process (AHP). Analytical Hierarchy Process (AHP) merupakan model yang memungkinkan kita mengambil keputusan dengan mengkombinasikan pertimbangan dan nilai-nilai pribadi secara logis.

Penyusunan strategi tersebut dilakukan oleh ahli-ahli yang kompeten dan mewakili yang berkaitan dengan alternatif yang akan disusun prioritasnya (Saaty, 1993). Ahli-ahli yang dipilih dalam mengidentifikasi prioritas kriteria dalam penentuan lokasi ibukota di Kabupaten Mojokerto terdiri dari:

1. Kepala Badan Perencanaan Pembangunan Daerah Kabupaten Mojokerto

2. Kepala Sub Bidang Perencanaan Bidang Penataan Ruang Dinas Pekerjaan Umum dan Penataan Ruang Kabupaten Mojokerto

3. Kepala Bagian Pemerintahan Sekretariat Daerah Kabupaten Mojokerto

4. Kepala Badan Pengelola Keuangan dan Aset Kabupaten Mojokerto

5. Dosen Jurusan Perencanaan Wilayah dan Kota Fakultas Teknik Universitas Brawijaya.

6. Konsultan Ahli Perencanaan Wilayah dan Kota (Perwakilan Ikatan Ahli Perencana Provinsi Jawa Timur)

7. Anggota Dewan/DPRD Kabupaten Mojokerto

8. Wakil Masyarakat

Adapun langkah-langkah dalam metode AHP adalah sebagai berikut:

1) Mengindentifikasi masalah dan menentukan solusi yang diinginkan, melalui diskusi dengan pakar yang mengetahui permasalahan serta dengan kajian referensi hingga diperoleh konsep yang relevan dengan permasalahan yang dihadapi.

2) Menyusun struktur hirarki yang dimulai dari tujuan umum, sub-tujuan, kriteria hingga penentuan sejumlah alternatif, berdasarkan permasalahan yang dihadapi, sedangkan penentuan kriteria dan alternatif diperoleh dari hasil observasi dan diskusi dengan pakar.

3) Menyebarkan kuesioner kepada pakar untuk penentuan pengaruh masing-masing elemen terhadap masing-masing aspek atau kriteria dengan membuat matriks perbandingan berpasangan (pairwise comparison). Pengisian matriks perbandingan berpasangan dengan menggunakan bilangan/skala yang mengambarkan kepentingan suatu elemen dibanding elemen yang lain.

4) Menyusun matrik pendapat individu dan gabungan dari hasil rata-rata yang diperoleh responden kemudian diolah dengan bantuan expert choice versi 9.0. Jika nilai konsistensinya $>0,1$ maka hasil jawaban tidak konsisten dan jika nilai konsistensinya $<0,1$ maka hasil jawaban konsisten.

5) Langkah selanjutnya adalah prioritas kriteria dan alternatif yang telah didapatkan tersebut digunakan untuk menyusun strategi. Skala kepentingan yang digunakan dalam metode AHP adalah sebagai berikut.

1 : Kedua elemen sama pentingnya (pengaruhnya sama besar)

3 : Elemen yang satu sedikit lebih penting daripada elemen yang lainnya

$5 \quad$ : Elemen yang satu lebih penting daripada yang lainnya

$7 \quad$ : Satu elemen jelas lebih mutlak penting dariapada elemen lainnya

9 : Satu elemen mutlak penting daripada elemen lainnya

$2,4,6,8$ : Nilai-nilai antara dua nilai pertimbangan-pertimbangan yang berdekatan, nilai ini diberikan bila ada dua kompromi di antara 2 pilihan

Pengolahan data dalam metode AHP pada penelitian dilakukan dengan menggunakan software Expert Choice 2000 2nd edition. Pada metode AHP terdapat perhitungan rasio konsistensi dengan melihat index konsistensi. Konsistensi yang diharapkan adalah yang mendekati sempurna agar menghasilkan keputusan yang mendekati valid.

Menurut Saaty (1993) indikator terhadap konsistensi diukur melalui Consistensy Index (CI) yang dirumuskan sebagai berikut :

$$
\begin{aligned}
& \mathrm{CI}=(\lambda \text { maks }-\mathrm{n}) /(\mathrm{n}-1) . \\
& \lambda \text { maks }=\text { eigen value maksimum } \\
& \mathrm{n}=\text { ukuran matriks. }
\end{aligned}
$$

AHP mengukur seluruh konsistensi penilaiaan dengan menggunakan Consistency Ratio (CR), yang perumusannya:

$\mathrm{CR}=$ CI

$\overline{\text { RandomConsistencyIndex }}$ 
Nilai CR semestinya tidak boleh lebih dari 10 $\%$. Jika tidak, berarti penilaian yang telah di buat mungkin dilakukan secara random dan perlu direvisi.

\section{HASIL DAN PEMBAHASAN}

\section{Gambaran Umum Kabupaten Mojokerto}

Kabupaten Mojokerto merupakan salah satu Kabupaten di Provinsi Jawa Timur yang terdiri dari 18 Kecamatan diantaranya adalah Kecamatan Jatirejo, Gondang, Pacet, Trawas, Ngoro, Pungging, Kutorejo, Mojosari, Bangsal, Mojoanyar, Dlanggu, Puri, Trowulan, Kecamatan Sooko, Gedeg, Jetis, Kemlagi, dan Dawar Blandong.

Pusat pemerintahan Kabupaten Mojokerto sebelumnya berada di Kota Mojokerto. Namun, seiring dengan perkembangan ekonomi serta pembangunan daerah Kabupaten Mojokerto, sehingga diperlukan adanya penentuan alternatif lokasi ibu kota kecamatan di Kabupaten Mojokerto. Adapun beberapa kecamatan yang menjadi alternatif yaitu Kecamatan Mojosari, Kecamatan Jetis, Kecamatan Sooko, Kecamatan Trowulan dan Kecamatan Bangsal. Berikut penjelasan dari masing-masing kecamatan.

\section{A. Kondisi Letak Geografis}

Kabupaten Mojokerto terdiri dari 18 Kecamatan diantaranya adalah Kecamatan Jatirejo, Gondang, Pacet, Trawas, Ngoro, Pungging, Kutorejo, Mojosari, Bangsal, Mojoanyar, Dlanggu, Puri, Trowulan, Kecamatan Sooko, Gedeg, Jetis, Kemlagi, dan Dawar Blandong. Adapun batas-batas wilayah Kabupaten Mojokerto adalah sebagai berikut:

Sebelah utara :Kabupaten Lamongan dan Kabupaten Gresik

Sebelah timur :Kabupaten Sidoarjo dan Pasuruan

Sebelah barat : Kabupaten Jombang

Sebelah selatan : Kabupaten Malang

Salah satu kriteria yang dapat menjelaskan kondisi geografis wilayah studi adalah jarak antara lokasi alternatif ibu Kota Kabupaten Mojokerto terhadap pusat pemerintahan lama. Adapun jarak antara lokasi alternatif ibu kota Kabupaten Mojokerto terhadap pusat pemerintahan yang lama sebagai berikut:

1. Kecamatan Mojosari memiliki jarak sejauh $15 \mathrm{~km}$ terhadap Kota Mojokerto

2. Kecamatan Jetis memiliki jarak sejauh 14 km terhadap Kota Mojokerto

3. Kecamatan Sooko memiliki jarak sejauh $5,2 \mathrm{~km}$ terhadap Kota Mojokerto

4. Kecamatan Trowulan memiliki jarak sejauh $12 \mathrm{~km}$ terhadap Kota Mojokerto
5. Kecamatan Bangsal memiliki jarak sejauh $10 \mathrm{~km}$ terhadap Kota Mojokerto

\section{B. Kondisi Fisik}

Kondisi fisik suatu wilayah penentuan lokasi alternatif ibu kota Kabupaten Mojokerto dapat dijelaskan berdasarkan kemiringan lereng, ketersediaan air bersih dan kerentanan bencana setiap daerah.

Kemiringan Lereng

1. Kecamatan Mojosari memiliki tingkat kemiringan lereng 0-2 derajat dengan luas wilayah pada tingkat kemiringan tersebut seluas 3044,88 Ha.

2. Kecamatan Jetis memiliki tiga klasifikasi tingkat kemiringan lereng yaitu $0-2$ derajat, 2-15 derajat dan 15-40 derajat. Adapun luas wilayah yang berada pada tingkat kemiringan lereng 0-2 derajat seluas 5008,33 Ha; kemiringan lereng 215 derajat seluas $48 \mathrm{Ha}$ dan kemiringan lereng 15-40 derajat seluas $32 \mathrm{Ha}$.

3. Kecatamatan Sooko memiliki tingkat kemiringan lereng 0-2 derajat dengan luas wilayah pada tingkat kemiringan tersebut seluas 2497,32 Ha

4. Kecamatan Trowulan memiliki tingkat kemiringan lereng yaitu 0-2 derajat, 2-15 derajat dan 15-40 derajat. Adapun luas wilayah yang berada pada tingkat kemiringan lereng 0-2 derajat seluas 4402,14 Ha; kemiringan lereng 2-15 derajat seluas $180 \mathrm{Ha}$ dan kemiringan lereng 15-40 derajat seluas $65 \mathrm{Ha}$.

5. Kecamatan Bangsal memiliki tingkat kemiringan lereng 0-2 derajat dengan luas wilayah pada tingkat kemiringan tersebut seluas $2373,70 \mathrm{Ha}$.

Ketersediaan Air Bersih

Berikut merupakan ketersediaan air bersih

di setiap lokasi alternatif pemilihan ibu kota Kabupaten Mojokerto.

1. Sebagian besar wilayah Kecamatan Mojosari memiliki kualitas air tanah yang baik dan sebagian besar masyarakat menggunakan sumur bor sebagai akses untuk mendapatkan air bersih. Selain itu juga terdapat lokasi sumber air baku PDAM di Kecamatan Mojosari berada di Desa Awang-awang dan Desa Candirejo.

2. Sebagian besar wilayah kecamatan Sooko memiliki kualitas air tanah yang baik dan sebagian besar masyarakat menggunakan sumur bor sebagai akses untuk mendapat kan air bersih. Adapun lokasi sumber air baku PDAM di Kecamatan Jetis berada di Desa Jetis. 
3. Wilayah Kecamatan Sooko memiliki kualitas air yang baik dengan keriteria tidak bewarna, berbau dan tidak berasa. Sebagian besar masyarakat Kecamatan Sooko menggunakan sumur sebagai akses mendapatkan air bersih.

4. Wilayah Kecamatan Trowulan memiliki kualitas air yang baik. Sebagian besar masyarakat juga menggunakan sumur sebagai akses mendapatkan air bersih. Adapun lokasi sumber air baku PDAM di Kecamatan Trowulan berada di Desa Domas

5. Wilayah Kecamatan Bangsal memiliki kualitas air yang baik dengan kriteria tidak bewarna, berbau dan tidak berasa. Sebagian besar masyarakat Kecamatan Sooko menggunakan sumur sebagai akses mendapatkan air bersih.

\section{Kerentanan Bencana}

Kerentanan bencana yang terjadi di Kabupaten Mojokerto diantaranya adalah kekeringan, tanah longsor dan banjir (Kementrian Bappenas, 2017).

1. Resiko Kekeringan

Resiko kekeringan tertinggi berada pada tengah wilayah punggung gunung di bagian selatan dan dataran rendah bagian utara Mojokerto. Lima kecamatan yang merupakan alternative lokasi Ibukoa Kabupaten, semuanya bukan merupakan Kawasan yang rawan resiko kekeringan.

2. Banjir

Berdasarkan RTRW Kabupaten Mojokerto, Kecamatan Bangsal, Mojosari dan Sooko merupakan wilayah yang merupakan Kawasan rawan bencana banjir

3. Longsor

Lima kecamatan yang merupakan alternative lokasi Ibukoa Kabupaten, semuanya bukan merupakan Kawasan yang rawan resiko longsor

\section{Ketersediaan Lahan}

Ketersediaan lahan dapat dijelaskan melalui beberapa aspek diantaranya luas lahan dan penggunaan lahan. Berikut penjelasan dari masing-masing ketersediaan lahan.

\section{Luas Lahan}

Lima kecamatan yang terpilih sebagai alternative ibukota Kabupaten Mojokerto rata-rata memiliki luas mulai 23,46 sampai $57,17 \mathrm{Km}^{2}$. Daerah terluas adalah Kecamatan Jetis dan yang terkecil adalah Kecamatan Sooko. Luas daerah tidak terkait langsung dengan potensi suatu kecamatan sebagai Ibukota Kabupaten, hanya saja terkait dengan ketersediaan lahan yang dibutuhkan dalam pengembangan fisik suatu Ibukota Kabupaten. Rincian luas daerah pada lima kecamatan terdapat pada Tabel 2.

Tabel 2. Tinggi Rata-Rata dari Permukaan Air Laut dan Luas Daerah masing-masing Kecamatan

\begin{tabular}{|l|c|r|}
\hline Kecamatan & $\begin{array}{c}\text { Tinggi rata-rata } \\
\text { dari permukaan } \\
\text { air laut (m) }\end{array}$ & $\begin{array}{c}\text { Luas Daerah } \\
\text { (Km2) }\end{array}$ \\
\hline Mojosari & 100 & 26,65 \\
\hline Bangsal & 60 & 24,06 \\
\hline Trowulan & 60 & 39,20 \\
\hline Sooko & 64 & 23,46 \\
\hline Jetis & 60 & 57,17 \\
\hline
\end{tabular}

\section{Penggunaan Lahan}

Lima kecamatan yang terpilih sebagai alternatif ibukota Kabupaten Mojokerto, penggunaan lahan rata-rata didominasi oleh penggunaan lahan sawah dengan proporsi hampir $50 \%$ dari total luas daerah. Proporsi Luas lahan sawah terbesar ada di Kecamatan Mojosari (62\%) sedangkan terkecil ada di Kecamatan Jetis (38\%). Diasumsikan bahwa semakin besar luas lahan sawah pada suatu kecamatan maka semakin kecil pula potensi lahan yang dapat mendukung pembangunan pada wilayah tersebut dikarenakan guna lahan sawah khususnya berupa sawah beririgasi teknis merupakan lahan produktif yang masih harus dipertahankan keberadaannya apabila memungkinkan. Namun secara fungsi perwilayahan, kelima kecamatan diatas memiliki fungsi sebagai pusat pelayanan/perkembangan kota sehingga perubahan alih fungsi lahan sawah sangat memungkinkan untuk terjadi.

\section{Historis}

Dari 5 kecamatan yang menjadi alternatif lokasi, Kecamatan yang mempunyai sejarah terkait dengan identitas Kabupaten Mojokerto adalah Kecamatan Trowulan. Kecamatan Trowulan memiliki Situs Trowulan yaitu kawasan kepurbakalaan dari periode klasik sejarah Indonesia. Situs Trowulan telah didaftarkan untuk menjadi Situs Warisan Dunia UNESCO sejak tahun 2009. RTRW Kabupaten Mojokerto tahun 2012-2032 telah menetapkan Kecamatan Trowulan sebagai Kawasan Strategis Cagar Budaya Nasional.

\section{E. Kebijakan}

Dalam rencana RTRW Kabupaten Mojokerto tahun 2012-2032, berdasarkan rencana pengembangan system perkotaan, lima kecamatan yang merupakan lokasi alternatif Ibukota, diarahkan menjadi 3 jenis 3 (tiga) Pusat Kegiatan yaitu 
1. Pusat Kegiatan Lokal "Promosi" (PKL Promosi)

2. Pusat Pelayanan Kawasan (PPK)

3. Pusat Pelayanan Lingkungan (PPL)

Berdasarkan kebijakan system perwilayahan, 2 kecamatan yaitu Kecamatan Jetis dan Sooko memiliki fungsi/hierarki pelayanan yang lebih tinggi dibandingkan Kecamatan Bangsal dan Trowulan. Namun secara keseluruhan fungsi, semua kecamatan memiliki potensi cepat tumbuh karena merupakan lokasi yang secara kebijakan merupakan wilayah yang punya fungsi sebagai pusat pelayanan baik skala local, Kawasan maupun regional.

\section{Penentuan Prioritas Alternatif Lokasi Ibukota Kabupaten \\ Prioritas Kriteria oleh Para Pakar}

Kriteria lokasi Ibukota Kabupaten adalah Letak geografis, Kondisi fisik, Ketersediaan lahan, Historis, Kebijakan, Politik dan keamanan, Aksesibilitas, Ketersediaan sarana prasarana dan Kependudukan. Antar kriteria tersebut dibandingkan oleh para pakar. Hasil perbandingan tersebut diperoleh dari kuesioner yang diberikan kepada para pakar dan diubah dalam bentuk matriks perbandingan berpasangan setiap kriteria lokasi Ibukota Kabupaten. Seluruh pendapat pakar digunakan untuk menentukan bobot kriteria.

Setelah diperoleh matriks perbandingan berpasangan setiap kriteria, selanjutnya ditentukan vektor bobot masing-masing yang dapat dilihat pada Tabel 3 yang menunjukkan hasil perhitungan consistency ratio diperoleh ukuran kekonsistensian pendapat pakar dalam mengisi kuesioner. Tabel 3 menunjukkan pendapat para pakar dalam membandingkan kriteria Lokasi Ibukota Kabupaten telah konsisten. Nilai $C R<0.1$ yang berarti tingkat konsistensinya $\geq 90 \%$, sehingga pernyataan pakar dapat menjadi acuan memprioritaskan langkah penentuan Alternatif Lokasi Ibukota Kabupaten Mojokerto. Setelah diperoleh nilai $\mathrm{CR} \leq 0.1$ untuk masingmasing penilaian pakar, maka selanjutnya dilakukan perhitungan rata-rata geometrik vektor bobot pakar untuk mengetahui urutan prioritas kriteria. Hasil perhitungan rata-rata geometrik vektor bobot pakar terdapat pada Tabel 4 .

Tabel 3. Vektor Bobot dan Consistensi Ratio Kriteria Lokasi Ibukota Kabupaten Mojokerto

\begin{tabular}{|c|c|c|c|c|c|c|c|c|c|}
\hline \multicolumn{2}{|c|}{ Keterangan } & $\begin{array}{c}\text { Pakar } \\
1 \\
\end{array}$ & $\begin{array}{c}\text { Pakar } \\
2 \\
\end{array}$ & $\begin{array}{c}\text { Pakar } \\
3 \\
\end{array}$ & $\begin{array}{c}\text { Pakar } \\
4 \\
\end{array}$ & $\begin{array}{c}\text { Pakar } \\
5 \\
\end{array}$ & $\begin{array}{c}\text { Pakar } \\
6 \\
\end{array}$ & $\begin{array}{c}\text { Pakar } \\
7 \\
\end{array}$ & $\begin{array}{c}\text { Pakar } \\
8 \\
\end{array}$ \\
\hline \multirow{9}{*}{$\begin{array}{l}\text { Vektor } \\
\text { Bobot }\end{array}$} & Letak Geografis & 0,047 & 0,058 & 0,224 & 0,070 & 0,029 & 0,134 & 0,05 & 0,035 \\
\hline & Kondisi Fisik & 0,200 & 0,237 & 0,128 & 0,092 & 0,084 & 0,040 & 0,142 & 0,080 \\
\hline & $\begin{array}{l}\text { Ketersediaan } \\
\text { Lahan }\end{array}$ & 0,371 & 0,343 & 0,109 & 0,261 & 0,099 & 0,160 & 0,240 & 0,087 \\
\hline & Historis & 0,022 & 0,026 & 0,034 & 0,034 & 0,228 & 0,023 & 0,025 & 0,049 \\
\hline & Kebijakan & 0,031 & 0,037 & 0,080 & 0,038 & 0,056 & 0,204 & 0,237 & 0,090 \\
\hline & $\begin{array}{l}\text { Politik Dan } \\
\text { Keamanan }\end{array}$ & 0,026 & 0,035 & 0,087 & 0,046 & 0,065 & 0,173 & 0,088 & 0,280 \\
\hline & Aksesibilitas & 0,041 & 0,044 & 0,180 & 0,237 & 0,152 & 0,102 & 0,175 & 0,166 \\
\hline & $\begin{array}{l}\text { Ketersediaan } \\
\text { Sarana } \\
\text { Prasarana } \\
\end{array}$ & 0,134 & 0,097 & 0,112 & 0,192 & 0,203 & 0,100 & 0,041 & 0,126 \\
\hline & Kependudukan & 0,129 & 0,123 & 0,046 & 0,030 & 0,085 & 0,064 & 0,038 & 0,087 \\
\hline \multicolumn{2}{|c|}{ Consistency Ratio } & 0,07 & 0,09 & 0,07 & 0,09 & 0,08 & 0,09 & 0,099 & 0,099 \\
\hline
\end{tabular}

Tabel 4 merupakan hasil perhitungan prioritas Kriteria penentuan Lokasi Ibukota Kabupaten Mojokerto dengan temuan bahwa berdasarkan urutan kriteria dari yang paling utama yang diperlukan oleh suatu Ibukota Kabupaten Mojokerto berdasarkan stakeholder adalah Ketersediaan lahan (1), aksesibilitas (2), ketersediaan sarana prasarana (3), kondisi fisik (4), politik dan keamanan (5), Kebijakan (6), kependudukan (7), letak geografis (8) dan historis (9). Ketersediaan lahan merupakan kriteria utama yang menentukan apakah suatu wilayah sesuai difungsikan sebagai Ibukota Kabupaten karena keberadaan lahan diperlukan dalam rangka mendukung pembangunan zona perkantoran terkait dengan fungsi pelayanan ibukota, juga diperlukan dalam mendukung perkembangan zona-zona lain yang tumbuh akibat keberadaan fungsi pelayanan tersebut.

Tabel 4. Bobot Final dan Urutan Prioritas Kriteria Lokasi Ibukota Kabupaten Mojokerto

\begin{tabular}{l|c|c} 
Kriteria & $\begin{array}{c}\text { Rata-Rata } \\
\text { Geometrik } \\
\text { Vektor Bobot } \\
\text { Para Pakar }\end{array}$ & $\begin{array}{c}\text { Urutan } \\
\text { Prioritas }\end{array}$ \\
\hline Letak Geografis & 0,076 & 8 \\
\hline Kondisi Fisik & 0,126 & 4 \\
\hline
\end{tabular}




\begin{tabular}{l|c|c}
\hline \multicolumn{1}{c|}{ Kriteria } & $\begin{array}{c}\text { Rata-Rata } \\
\text { Geometrik } \\
\text { Vektor Bobot } \\
\text { Para Pakar }\end{array}$ & $\begin{array}{c}\text { Urutan } \\
\text { Prioritas }\end{array}$ \\
\hline $\begin{array}{l}\text { Ketersediaan } \\
\text { Lahan }\end{array}$ & 0,213 & 1 \\
\hline Historis & 0,045 & 9 \\
\hline Kebijakan & 0,088 & 6 \\
\hline $\begin{array}{l}\text { Politik Dan } \\
\text { Keamanan }\end{array}$ & 0,091 & 5 \\
\hline Aksesibilitas & 0,144 & 2 \\
\hline $\begin{array}{l}\text { Ketersediaan } \\
\text { Sarana Prasarana }\end{array}$ & 0,139 & 3 \\
\hline Kependudukan & 0,077 & 7 \\
\hline
\end{tabular}

Tabel 5. Urutan Prioitas Kriteria Lokasi Ibukota Kabupaten Mojokerto

\begin{tabular}{c|l}
\hline $\begin{array}{c}\text { Urutan } \\
\text { Prioritas }\end{array}$ & \multicolumn{1}{c}{ Kriteria } \\
\hline 1 & Ketersediaan Lahan \\
\hline 2 & Aksesibilitas \\
\hline 3 & Ketersediaan Sarana Prasarana \\
\hline 4 & Kondisi Fisik \\
\hline 5 & Politik Dan Keamanan \\
\hline
\end{tabular}

\begin{tabular}{c|l}
\hline $\begin{array}{c}\text { Urutan } \\
\text { Prioritas }\end{array}$ & \multicolumn{1}{c}{ Kriteria } \\
\hline 6 & Kebijakan \\
\hline 7 & Kependudukan \\
\hline 8 & Letak Geografis \\
\hline 9 & Historis \\
\hline
\end{tabular}

\section{Hasil pemrioritasan Kriteria dan Alternatif}

Melalui AHP telah diketahui bobot kriteria dan alternatif Lokasi Ibukota Kabupaten Mojokerto. Konsistensi pendapat para pakar telah memenuhi kriteria syarat ketidakkonsistenan di bawah $10 \%$ yang ditunjukkan oleh nilai consistency ratio $\leq 0,1$. Oleh karena itu, hasil pebobotan layak digunakan sebagai penentu alternatif Lokasi Ibukota Kabupaten Mojokerto.

Hasil dari lokasi terpilih ditunjukkan pada Tabel 5 dan Tabel 6 dengan prirotas lokasi terpilih berdasarkan prioritas kriteria adalah Kecamatan Mojosari (1), Kecamatan Sooko (2), Kecamatan Trowulan (3), Kecamatan Jetis (4) dan Kecamatan Bangsal (5).

Tabel 6. Bobot Final dan Urutan Prioritas Lokasi Ibukota Kabupaten Mojokerto Berdasarkan 8 pakar

\begin{tabular}{|c|c|c|c|c|c|c|c|c|c|c|c|}
\hline & & $\begin{array}{c}\text { Pakar } \\
1\end{array}$ & $\begin{array}{c}\text { Pakar } \\
2\end{array}$ & $\begin{array}{c}\text { Pakar } \\
3\end{array}$ & $\begin{array}{c}\text { Pakar } \\
4\end{array}$ & $\begin{array}{c}\text { Pakar } \\
5\end{array}$ & $\begin{array}{c}\text { Pakar } \\
6\end{array}$ & $\begin{array}{c}\text { Pakar } \\
7\end{array}$ & $\begin{array}{c}\text { Pakar } \\
8\end{array}$ & $\begin{array}{c}\text { Nilai } \\
\text { Bobot } \\
\text { Final }\end{array}$ & $\begin{array}{l}\text { Prio } \\
\text { ritas }\end{array}$ \\
\hline \multirow{5}{*}{$\begin{array}{l}\text { Vektor } \\
\text { Bobot }\end{array}$} & $\begin{array}{l}\text { Kec. } \\
\text { Mojosari }\end{array}$ & 0,285 & 0,247 & 0,302 & 0,314 & 0,484 & 0,353 & 0,356 & 0,557 & 0,351 & 1 \\
\hline & $\begin{array}{l}\text { Kec. } \\
\text { Jetis }\end{array}$ & 0,233 & 0,327 & 0,198 & 0,288 & 0,109 & 0,101 & 0,089 & 0,042 & 0,157 & 4 \\
\hline & Kec. Sooko & 0,232 & 0,180 & 0,267 & 0,203 & 0,120 & 0,196 & 0,234 & 0,158 & 0,195 & 2 \\
\hline & $\begin{array}{l}\text { Kec. } \\
\text { Bangsal }\end{array}$ & 0,120 & 0,108 & 0,110 & 0,093 & 0,123 & 0,250 & 0,143 & 0,106 & 0,137 & 5 \\
\hline & $\begin{array}{l}\text { Kec. } \\
\text { Trowulan }\end{array}$ & 0,130 & 0,139 & 0,123 & 0,103 & 0,163 & 0,101 & 0,178 & 0,138 & 0,161 & 3 \\
\hline \multicolumn{12}{|c|}{$\lambda$ Maksimal } \\
\hline \multirow{2}{*}{\multicolumn{2}{|c|}{ Consistency Index }} & 0,08 & 0,08 & 0,06 & 0,08 & 0,07 & 0,09 & 0,09 & 0,10 & & \\
\hline & & & & & & & & & & & \\
\hline
\end{tabular}

Tabel 7. Bobot Final dan Urutan Prioritas Kriteria dan Aalternatif Lokasi Ibukota Kabupaten Mojokerto

\begin{tabular}{|c|c|c|c|c|c|c|c|c|c|c|}
\hline \multirow{2}{*}{ Kriteria } & \multicolumn{2}{|c|}{ Kecamatan Mojosari } & \multicolumn{2}{|c|}{$\begin{array}{c}\text { Kecamatan } \\
\text { Sooko }\end{array}$} & \multicolumn{2}{|c|}{$\begin{array}{c}\text { Kecamatan } \\
\text { Trowulan }\end{array}$} & \multicolumn{2}{|c|}{$\begin{array}{c}\text { Kecamatan } \\
\text { Jetis }\end{array}$} & \multicolumn{2}{|c|}{$\begin{array}{c}\text { Kecamatan } \\
\text { Bangsal }\end{array}$} \\
\hline & $\begin{array}{l}\text { Bobot } \\
\text { Final }\end{array}$ & $\begin{array}{c}\text { Urutan } \\
\text { Prioritas }\end{array}$ & $\begin{array}{l}\text { Bobot } \\
\text { Final }\end{array}$ & $\begin{array}{c}\text { Urutan } \\
\text { Prioritas }\end{array}$ & $\begin{array}{l}\text { Bobot } \\
\text { Final }\end{array}$ & $\begin{array}{c}\text { Urutan } \\
\text { Prioritas }\end{array}$ & $\begin{array}{l}\text { Bobot } \\
\text { Final }\end{array}$ & $\begin{array}{c}\text { Urutan } \\
\text { Prioritas }\end{array}$ & $\begin{array}{l}\text { Bobot } \\
\text { Final }\end{array}$ & $\begin{array}{c}\text { Urutan } \\
\text { Prioritas }\end{array}$ \\
\hline $\begin{array}{l}\text { Letak } \\
\text { Geografis }\end{array}$ & 0,373 & 4 & 0,222 & 3 & 0,153 & 5 & 0,143 & 4 & 0,109 & 4 \\
\hline $\begin{array}{l}\text { Kondisi } \\
\text { Fisik } \\
\end{array}$ & 0,347 & 6 & 0,179 & 7 & 0,167 & 3 & 0,152 & 2 & 0,155 & 3 \\
\hline $\begin{array}{l}\text { Ketersedia } \\
\text { an Lahan }\end{array}$ & 0,249 & 7 & 0,140 & 9 & 0,196 & 2 & 0,229 & 1 & 0,186 & 1 \\
\hline Historis & 0,212 & 9 & 0,157 & 8 & 0,406 & 1 & 0,150 & 3 & 0,075 & 8 \\
\hline Kebijakan & 0,477 & 1 & 0,212 & 5 & 0,078 & 8 & 0,133 & 6 & 0,099 & 5 \\
\hline $\begin{array}{l}\text { Politik } \\
\text { Dan } \\
\text { Keamanan }\end{array}$ & 0,423 & 8 & 0,186 & 6 & 0,155 & 4 & 0,141 & 5 & 0,094 & 6 \\
\hline $\begin{array}{l}\text { Aksesibilit } \\
\text { as }\end{array}$ & 0,373 & 5 & 0,219 & 4 & 0,141 & 6 & 0,103 & 8 & 0,164 & 2 \\
\hline $\begin{array}{l}\text { Ketersedia } \\
\text { an Sarana } \\
\text { Prasarana }\end{array}$ & 0,455 & 3 & 0,297 & 1 & 0,077 & 9 & 0,108 & 7 & 0,063 & 9 \\
\hline $\begin{array}{l}\text { Kependud } \\
\text { ukan }\end{array}$ & 0,471 & 2 & 0,250 & 2 & 0,107 & 7 & 0,083 & 9 & 0,089 & 7 \\
\hline
\end{tabular}




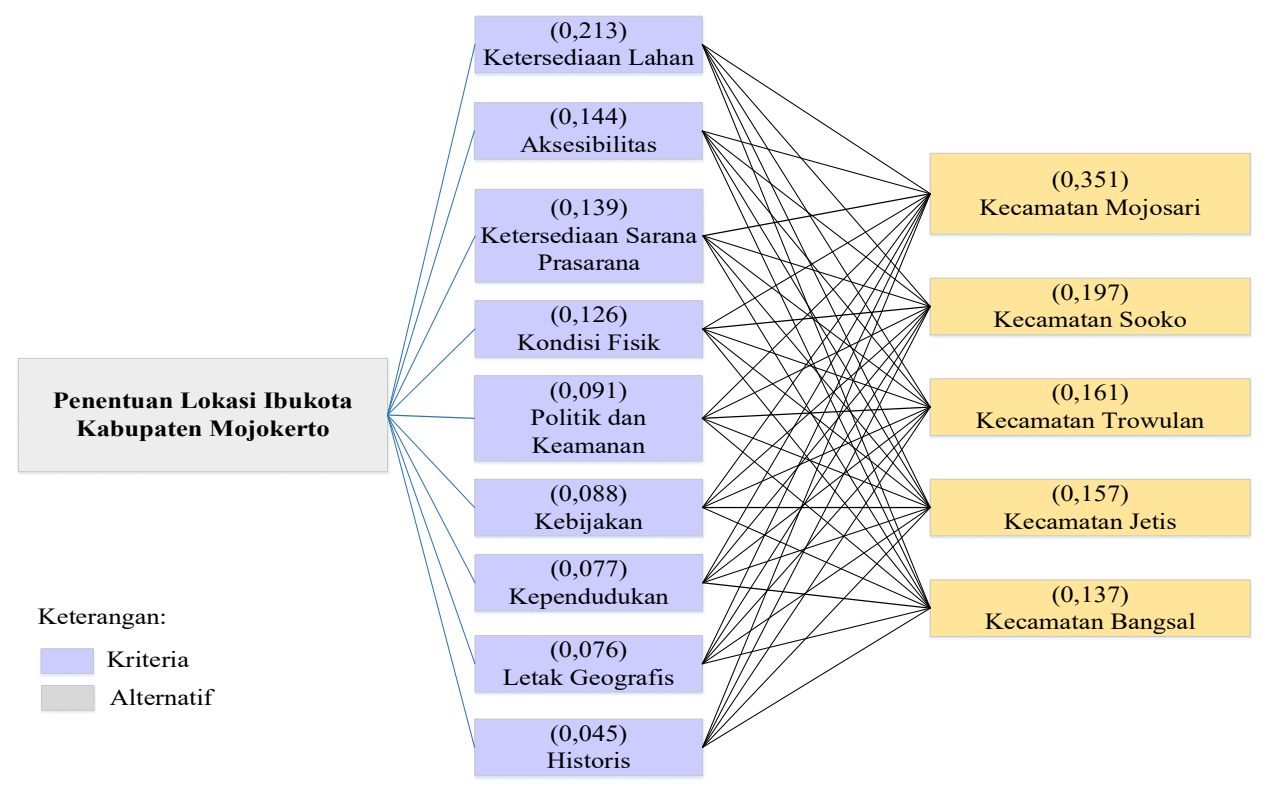

Gambar 1. Hierarki dan Bobot Prioritas Kriteria Lokasi Ibukota Kabupaten Mojokerto

Pada Kecamatan Mojosari menurut informasi Tabel 6, Kecamatan Mojosari aspek yang diprioritaskan adalah kriteria kebijakan, Kecamatan Sooko aspek yang diprioritaskan adalah kriteria Ketersediaan Sarana Prasarana, Kecamatan Trowulan aspek yang diprioritaskan adalah Kriteria Historis, Kecamatan Jetis aspek yang diprioritaskan adalah Ketersediaan Lahan dan Kecamatan Bangsal aspek yang diprioritaskan adalah Ketersediaan lahan.

Berdasarkan prioritas kriteria di Kecamatan Mojosari, aspek kebijakan memang dianggap paling mempengaruhi dikarenakan sangat penting memperhatikan acuan ketentuan pengembangan wilayah yang telah ditetapkan sehingga pada umumnya pakar sepakat bahwa aspek kebijakan untuk di Kecamatan Mojosari menjadi aspek utama. Peraturan Daerah Kabupaten Mojokerto Nomor 9 Tahun 2012 tentang Rencana Tata Ruang Wilayah Tahun 2012 - 2032 telah menetapkan/merencanakan Kecamatan Mojosari sebagai Pusat Pemerintahan sejak tahun 2012.

\section{KESIMPULAN}

Berdasarkan hasil penelitian terhadap penetuan alternatif lokasi Ibukota Kabupaten Mojokerto berdasarkan stakeholder, diperoleh kesimpulan sebagai berikut:

1. Hasil identifikasi kriteria dalam menentukan lokasi Ibukota, urutan kriteria yang diperlukan oleh suatu Ibukota Kabupaten Mojokerto berdasarkan stakeholder adalah Ketersediaan lahan (1), aksesibilitas (2), ketersediaan sarana prasarana (3), kondisi fisik (4), politik dan keamanan (5), Kebijakan (6), kependudukan (7), letak geografis (8) dan historis (9). Ketersediaan lahan merupakan kriteria utama yang menentukan apakah suatu wilayah sesuai difungsikan sebagai Ibukota Kabupaten karena keberadaan lahan diperlukan dalam rangka mendukung pembangunan zona perkantoran terkait dengan fungsi pelayanan ibukota, juga diperlukan dalam mendukung perkembangan zona-zona lain yang tumbuh akibat keberadaan fungsi pelayanan tersebut.

2. Alternatif Lokasi Terpilih Ibukota Kabupaten Mojokerto yang dipertimbangkan dari setiap kriteria, berdasarkan urutan 9 kriteria berdasarkan stakeholder maka lokasi yang terpilih berdasarkan prioritasnya adalah Kecamatan Mojosari (1), Kecamatan Sooko (2), Kecamatan Jetis (3), Kecamatan Trowulan (4) dan Kecamatan Bangsal (5).

3. Pada Kecamatan Mojosari, aspek yang diprioritaskan adalah kriteria kebijakan, Kecamatan Sooko aspek yang diprioritaskan adalah kriteria Ketersediaan Sarana Prasarana, Kecamatan Trowulan aspek yang diprioritaskan adalah Kriteria Historis, Kecamatan Jetis aspek yang diprioritaskan adalah Ketersediaan Lahan dan Kecamatan Bangsal aspek yang diprioritaskan adalah Ketersediaan lahan.

\section{DAFTAR PUSTAKA}

Peraturan Daerah Kabupaten Mojokerto Nomor 9 Tahun 2012 tentang Rencana Tata Ruang Wilayah (RTRW) Kabupaten 
Mojokerto tahun 2012 - 2032

Peraturan Menteri Dalam Negeri Nomor 32 Tahun 2012 tentang Pedoman Pemberian Nama Daerah, Pemberian Nama Ibu Kota, Perubahan Nama Daerah, Perubahan Nama Ibu Kota, Dan Pemindahan Ibu Kota

Peraturan Pemerintah Nomor 78 Tahun 2007 tentang Tata Cara Pembentukan, Penghapusan, dan Penggabungan Daerah
Saaty, Thomas. (1986). Pengambilan Keputusan Bagi Para Pemimpin. Jakarta: PT Pustaka Binaman Pressindo.

Undang-Undang No. 25 Tahun 2009 tentang Pelayanan Publik.

Undang-Undang No. 26 Tahun 2007 tentang Penataan Ruang.

Undang-Undang No. 32 Tahun 2004 tentang Pemerintah Daerah.

Undang-Undang No. 23 Tahun 2014 tentang Pemerintah Daerah. 
Iman Tunas Pratama, Soesilo Zauhar, Mochamad Rozikin 